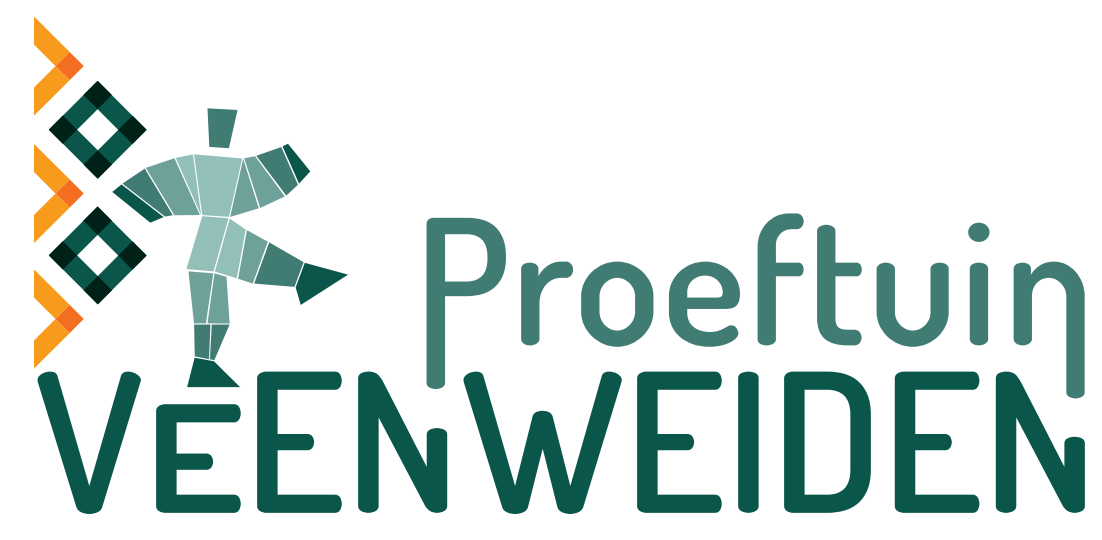

Eerste verkenning arrangementen om ammoniakemissie in het westelijke veenweidegebied te reduceren

Gerard Migchels, Marieke van Leeuwen, Leo Joosten

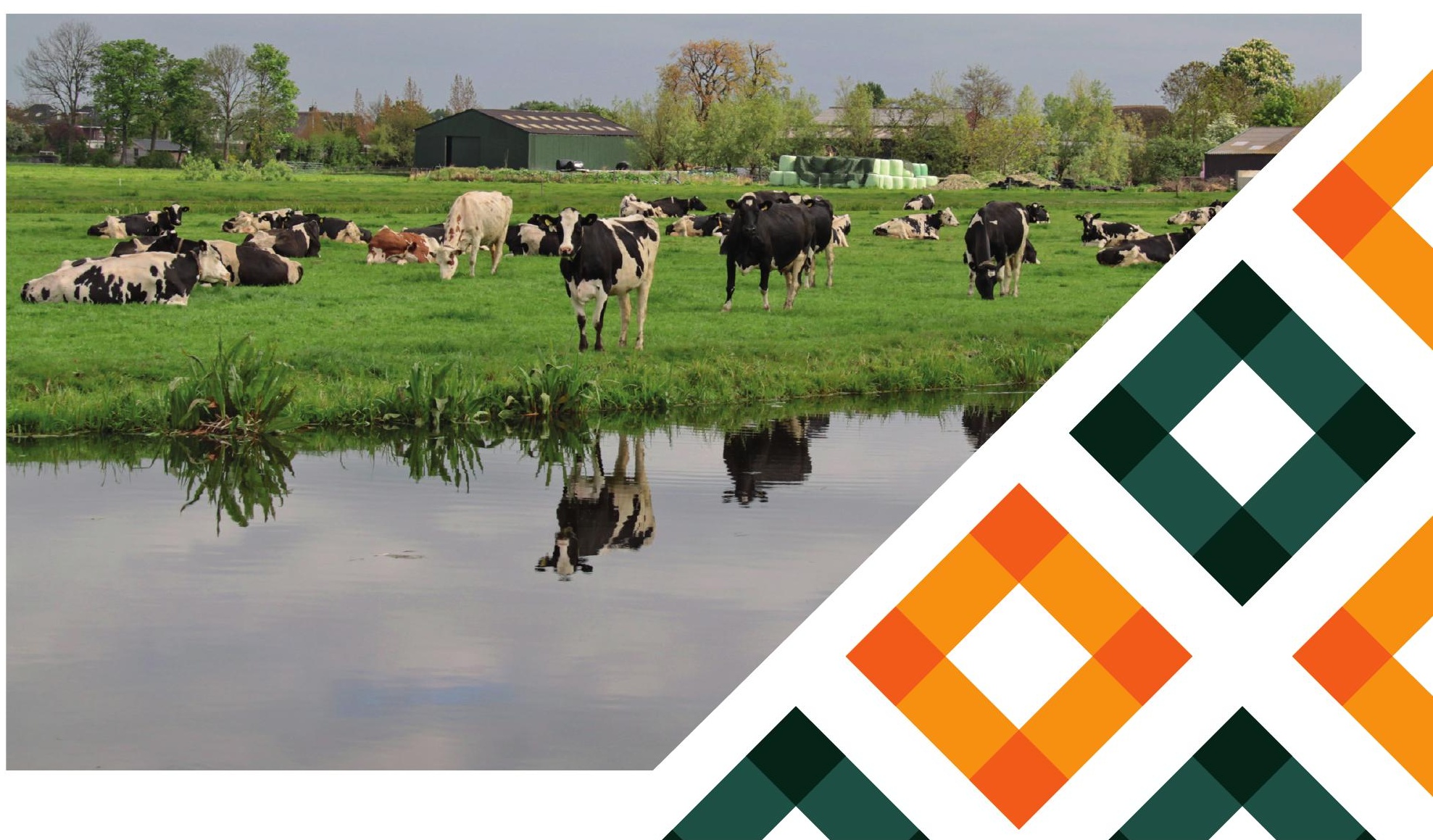





\title{
Eerste verkenning arrangementen om ammoniakemissie in het westelijke veenweidegebied te reduceren
}

Gerard Migchels ${ }^{1}$, Marieke van Leeuwen², Leo Joosten ${ }^{3}$

\author{
1 Wageningen Livestock Research \\ 2 Projecten LTO Noord \\ 3 ORG-ID
}

LTO Noord startte begin 2016 met het innovatieprogramma Proeftuin Veenweiden en wordt daarbij financieel ondersteund door provincie Zuid-Holland, het Ministerie van Economische Zaken, het Melkveefonds en het LTO Noord Fonds. De Proeftuin is een initiatief van LTO Noord en VIC Zegveld. De uitvoering van het programma is in handen van LTO Noord, Wageningen University \& Research, VIC Zegveld, PPP-Agro Advies, ORG-ID en het Louis Bolk Instituut. 
Gerard Migchels, Marieke van Leeuwen, Leo Joosten, 2019. Eerste verkenning arrangementen om ammoniakemissie in het westelijke veenweidegebied te reduceren. Wageningen Livestock Research, Rapport 1195.

Dit rapport is gratis te downloaden op https://doi.org/10.18174/500786 of op www.wur.nl/livestock-research (onder Wageningen Livestock Research publicaties).

(C) 2019 Wageningen Livestock Research

Postbus 338, 6700 AH Wageningen, T 03174839 53, E info.livestockresearch@wur.nl, www.wur.nl/livestock-research. Wageningen Livestock Research is onderdeel van Wageningen University \& Research.

Wageningen Livestock Research aanvaardt geen aansprakelijkheid voor eventuele schade voortvloeiend uit het gebruik van de resultaten van dit onderzoek of de toepassing van de adviezen.

Alle rechten voorbehouden. Niets uit deze uitgave mag worden vermenigvuldigd en/of openbaar gemaakt worden door middel van druk, fotokopie, microfilm of op welke wijze dan ook zonder voorafgaande toestemming van de uitgever of auteur.

Wageningen Livestock Research is NEN-EN-ISO 9001:2015 gecertificeerd. Op al onze onderzoeksopdrachten zijn de Algemene Voorwaarden van de Animal Sciences Group van toepassing. Deze zijn gedeponeerd bij de Arrondissementsrechtbank Zwolle.

Wageningen Livestock Research Rapport 1195 


\section{Inhoud}

$\begin{array}{ll}\text { Samenvatting } & \mathbf{5}\end{array}$

1

$\begin{array}{ll}\text { Inleiding } & \mathbf{7}\end{array}$

$\begin{array}{lll}1.1 & \text { Wat zijn de ambities van de Proeftuin Veenweiden? } & 7\end{array}$

$\begin{array}{lll}1.2 & \text { Wat zijn de potentiële mogelijkheden in het veenweidegebied? } & 7\end{array}$

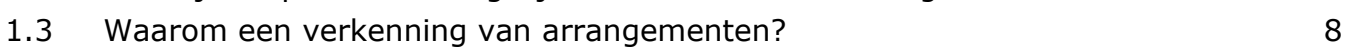

1.4 Doelstelling $\quad 8$

$\begin{array}{lll}1.5 & \text { Leeswijzer } & 8\end{array}$

2

$\begin{array}{ll}\text { Aanpak } & 9\end{array}$

3

$\begin{array}{lr}\text { Resultaten } & 10\end{array}$

3.1 Verkenning: drie mogelijke arrangementen 10

3.2 Verdieping van de drie arrangementen 10

3.2.1 Ketengerichte arrangementen 10

3.2.2 Integrale gebiedsgerichte arrangementen 12

3.2.3 Depositiegerichte arrangementen 13

3.3 Feedback van stakeholders op de drie arrangementen $\quad 14$

3.3.1 Feedback op het ketengerichte arrangement 14

3.3.2 Feedback op het integraal gebiedsgerichte arrangement $\quad 14$

3.3.3 Feedback op het depositiegerichte arrangement $\quad 15$

3.3.4 Beleidsgerichte 'arrangementen' 16 



\section{Samenvatting}

\section{Ambities Proeftuin Veenweiden}

De Proeftuin Veenweiden heeft een hoge ambitie: een vermindering van de ammoniakemissie in het westelijke veenweidegebied van $1,5-2,6$ kton in 2030, overeenkomend met een vermindering van de emissie op bedrijfsniveau van 25-40\%. Bij voorkeur moeten deze oplossingen ook bijdragen aan de oplossing van andere problemen in het veenweidegebied, als waterkwaliteit, bodemdaling en biodiversiteit. Een laatste ambitie is om bij te dragen aan ruimte voor ontwikkeling van andere sectoren.

De Proeftuin onderzoekt daartoe bovenwettelijke maatregelen, onderbouwt deze en toetst deze aan de praktijk van melkveebedrijven ('pilotboeren'). Maar de Proeftuin is pas geslaagd als deze bovenwettelijke maatregelen ook kans maken om daadwerkelijk op grote schaal te worden geïmplementeerd.

De Proeftuin zoekt daarom allereerst naar economische en praktische voordelen van maatregelen. Dat maakt het nemen ervan aantrekkelijk. Een tweede zoekrichting richt zich op arrangementen met andere partijen, waarbij dezen verleid worden om (uit welbegrepen eigenbelang) de melkveehouder (financieel) tegemoet te komen, als deze bovenwettelijke maatregelen neemt. Dat gebeurt alleen als er sprake is van win-win. Dit rapport beschrijft de eerste verkenning van mogelijke arrangementen.

\section{Eerste verkenning arrangementen}

De kernvraag is dus: hoe kunne arrangementen om emissie/depositie van ammoniak te verminderen er uit zien? Drie mogelijk kansrijke arrangementen zijn verkend:

- Ketengerichte arrangementen. Is het mogelijk om de voer- en zuivelketen te interesseren voor vermindering van ammoniakemissie? Relevante vragen daarbij: welke mogelijkheden zijn er tot vermindering van de overmaat aan eiwit in het rantsoen via het voerspoor? Welke mogelijkheden zijn er om via extra weidegang de ammoniakemissie te verminderen? Kan vermindering van ammoniakemissie onderdeel worden van de maatschappelijke doelen van de zuivelketen?

- Integraal gebiedsgerichte arrangementen. Kunnen ammoniakdoelen worden gehaald door ze te combineren met andere gebiedsdoelen? Relevante vragen daarbij: welke maatregelen om de ammoniakemissie te reduceren zijn denkbaar? In hoeverre sporen deze maatregelen met maatregelen gericht op verbetering van de waterkwaliteit en minder bodemdaling en CO2uitstoot? En wat zou de boer daarvoor terug kunnen krijgen?

- Depositiegericht arrangementen. Kan de melkveehouderij, tegen betaling, een deel van de $\mathrm{N}$ depositie-opgave van andere partijen (zoals de Rotterdamse haven) overnemen, onder afroming van een deel van de depositierechten? Relevante vragen daarbij: hoe doorbreken we daarbij de huidige strikte scheiding tussen landbouw en industrie in het $\mathrm{N}$-depositiebeleid? Hoe koppel je emissie aan depositie? Hoe kun je lange termijn contracten sluiten? Welke rol kan een Stikstofbank daarbij spelen? Hoe en hoeveel zou je moeten afromen om te zorgen dat de natuur er ook van profiteert?

\section{Conclusies en aanbevelingen}

Er liggen mogelijkheden om agrariërs via keten-, gebiedsgerichte of depositiegerichte arrangementen te verleiden tot maatregelen die de ammoniakemissie verminderen. Daarbij is wel nog sprake van de nodige belemmeringen, voetangels en klemmen van praktische, principiële en methodologische aard. Aanbevolen wordt om de 3 arrangementen verder uit te werken (te "ontwerpen") in samenspraak met betrokkenen.

Daarnaast is er feitelijk nog sprake van een vierde spoor: namelijk de mogelijkheid om via het beleidsspoor (wet- en regelgeving) bepaalde maatregelen dwingend op te leggen. Ook dit spoor wordt verkend. 
Voor de opbrengsten van die uitwerkingen wordt verwezen naar de volgende Proeftuin-publicaties:

\section{Ketengericht}

- Rapport: "Naar een ketengerichte aanpak om ammoniakemissie te reduceren. Ontwerp en toetsing"

\section{Gebiedsgericht}

- Rapport: "Naar een integraal gebiedsgerichte aanpak om ammoniakemissie te reduceren. Ontwerp en pilot".

- Rapportage "Van Proeftuin Veenweiden naar Klimaatslim Boeren op Veen"

Depositiegericht

- Rapportage "Mogelijkheden tot vermarkten reducties in ammoniakemissie in het westelijk veenweidegebied"

- Rapport: "Naar een depositiegerichte aanpak van ammoniakemissies rond de Nieuwkoopse Plassen"

\section{Beleidsgericht}

- Rapportage: "Effect van het sleepvoetverbod op de ammoniakemissie"

- Rapport: "Borgen van maatregelen die ammoniakemissie reduceren" 


\section{$1 \quad$ Inleiding}

\subsection{Wat zijn de ambities van de Proeftuin Veenweiden?}

De hoofdambitie van de Proeftuin Veenweiden is het realiseren van extra ammoniakreductie in de melkveehouderij in het westelijke veenweidegebied. Waar mogelijk in combinatie met een betere waterkwaliteit, minder bodemdaling, minder $\mathrm{CO} 2$ emissie en meer weidegang. Waardoor ook extra ruimte wordt gecreëerd voor verdere economische ontwikkeling in de melkveehouderij en in andere sectoren.

De hoofdambitie gekwantificeerd

Deze hoofdambitie is als volgt gekwantificeerd: het doel is om in 2030 in de westelijke Veenweiden een extra reductie van de ammoniakemissie van minimaal 1,5 kton te realiseren en bij voorkeur zelfs van 2,6 kton.

Deze reductie komt bovenop de beoogde reductie van 0,5-1 kton reductie via generieke maatregelen, zoals vastgelegd in het convenant tussen de landbouwsector en het Ministerie van EZ (tegenwoordig weer LNV).

Vertaald naar bedrijfsniveau (komt een reductie van 1,5 kton ongeveer overeen met een reductie van de ammoniakemissie met $25 \%$. Een ambitie van 2,6 kton komt overeen met een reductie van $40 \%$.

\section{De aanvullende ambities}

De andere ambities van de Proeftuin zijn kwalitatief verwoord:

- Er voor zorgen dat ammoniakmaatregelen niet ten koste gaan van, maar bijdragen aan oplossing van andere problemen in het veenweidegebied: bodemdaling, CO2-uitstoot, waterkwaliteit en biodiversiteit.

- Bij te dragen aan ruimte voor ontwikkeling van andere economische sectoren. De westelijke veenweidegebieden liggen midden in de Randstad en zijn omringd door industriële bedrijven en verkeerswegen, die ook bijdragen aan de stikstofbelasting van natuurgebieden. Hier dreigt een voortdurend gebrek aan ontwikkelruimte als gevolg van te hoge stikstofemissies door groei van de activiteiten. Welke transacties zijn mogelijk zijn, met winst voor industrie, melkveehouderij en natuur?

\subsection{Wat zijn de potentiële mogelijkheden in het veenweidegebied?}

Naast algemene (management)maatregelen, zoals ook al verkend in de Proeftuin Natura 2000 (www.proeftuinnatura2000.nl), is er in veenweidegebieden sprake van extra mogelijkheden via specifieke veenweide-maatregelen. Deze vinden hun oorsprong in de karakteristieken van de grondsoort veen. Met name het hoge organische stofgehalte van de bodem, met een lage draagkracht en een hoge $\mathrm{N}$-nalevering, leiden tot afwijkende bedrijfsvoeringen. Zo zijn er in het veenweidegebied minder mogelijkheden om dierlijke mest optimaal aan te wenden, is er sprake van andere beweidingspatronen en wordt het veenweidegebied gekenmerkt door rantsoenen met een hoog ruweiwit gehalte. En dat alles leidt weer tot een afwijkend patroon van ammoniakemissie en (meestal ook tot hogere ammoniakemissies) dan elders.

De andere kant van die medaille is dat er dan ook specifieke veenweidemaatregelen mogelijk zijn om de ammoniakemissie te beperken. (zie de tabel hiernaast, met een indicatie van de bijbehorende emissiereductie). De mogelijkheden om die emissie te beperken (via managementmaatregelen) worden zelfs hoog ingeschat: met een combi van deze maatregelen zou een ammoniakreductie van $25 \%$ op bedrijfsniveau mogelijk moeten zijn, met een doorkijk naar 40\% (Evers et al 2019). 


\begin{tabular}{ll} 
Specifieke veenweidemaatregelen & Emissiereductie \\
\hline Meer kruiden in het gras & ca $12 \% *$ \\
\hline Vroeg baggeren & ca $0-3 \% *$ \\
\hline Onderwaterdrainage & ca $3-10 \% *$ \\
\hline Anders / minder bemesten & ca $0-3 \% *$ \\
\hline Betere Ca / Mg verhouding bodem & ca $0-3 \% *$ \\
\hline Eiwitarme grasrassen & ca $7 \% *$ \\
\hline Algemene maatregel & \\
\hline extra weidegang & $5-15 \%$ \\
\hline stal: sproeien met water & $0-15 \%$ \\
\hline stal: dakisolatie en ventilatie & $5-10 \%$ \\
\hline stal: andere vloeren & $5-30 \%$ \\
\hline$*$ ) ruwe inschatting, onderzoek loopt om dit te concretiseren & \\
\hline
\end{tabular}

\subsection{Waarom een verkenning van arrangementen?}

Waarom zou een melkveehouder zich inzetten om extra ammoniakemissie-reductie te realiseren? Als hij beschikt over een Natuurbeschermingswetvergunning is daartoe geen enkele noodzaak (behalve als er nieuwe regels worden opgelegd, maar dan gaat het om het bovengenoemde generieke traject en niet om het specifieke veenweide-traject). Dan is het dus zaak om de melkveehouder te "verleiden". En dan kom je al gauw terecht bij financiële prikkels.

Twee lijnen voor financiële prikkels

De Proeftuin werkt daarbij langs twee lijnen:

- Een eerste "directe" lijn ligt in de economische en praktische voordelen van maatregelen: lagere kosten, hogere opbrengsten of minder arbeidsinzet maken het nemen van maatregelen aantrekkelijk. Dat heeft verrassende mogelijkheden opgeleverd, waarover wordt gerapporteerd in het Proeftuin-rapport "Effecten van ammoniak-reducerende maatregelen in bedrijfsverband" (Evers et al 2019).

- Een tweede "indirecte" lijn ligt in arrangementen, waarbij andere partijen verleid worden om (uit welbegrepen eigenbelang) de melkveehouder (financieel) tegemoet te komen als hij bovenwettelijke maatregelen neemt ter reductie van de ammoniakemissie. Daar horen arrangementen bij. Daarover gaat dit rapport.

\section{$1.4 \quad$ Doelstelling}

Het doel van deze verkenning is om kansrijke arrangementen te identificeren die leiden tot aanvullende verdienmogelijkheden voor melkveehouders als zij bovenwettelijke ammoniakreducerende maatregelen nemen.

\subsection{Leeswijzer}

In hoofdstuk 2 is de aanpak van de verkenning beschreven. Hoofdstuk 3 beschrijft de uitkomsten. En hoofdstuk 4 bevat conclusies en aanbevelingen. 


\section{Aanpak}

Hoe zouden arrangementen om emissie en depositie van ammoniak te verminderen er uit kunnen zien? Om daar zicht op te krijgen zijn de wensen en behoeften van betrokken stakeholders in kaart gebracht en uitgewerkt in 3 stappen.

\section{Stap 1}

Allereerst zijn gesprekken gevoerd met vertegenwoordigers vanuit de zuivelketen, agrarische natuurverenigingen, natuur- \& milieubeschermingsorganisaties, de Rotterdamse haven, overheden (provincie \& Rijk) en diverse adviseurs. Voor een overzicht van de geïnterviewden, zie bijlage 1.

\section{Stap 2}

Vervolgens zijn de inzichten die dat opleverde verdiept via literatuurstudie en via een interne workshop. Voor de deelnemers aan die workshop, zie bijlage 1.

\section{Stap 3}

Tenslotte is feedback verkregen op de ontwikkelde ideeën op een workshop in december 2016. Voor de deelnemers aan deze workshop, zie bijlage 1. 


\subsection{Verkenning: drie mogelijke arrangementen}

De Proeftuin Veenweiden zoekt naar bovenwettelijke ammoniak-reducerende maatregelen in de melkveehouderij in het westelijke veenweidegebied en onderbouwt zowel de effectiviteit als kosten en baten wetenschappelijk. Ook toetst de Proeftuin de geselecteerde maatregelen aan de dagelijkse praktijk van melkveebedrijven.

Maar de Proeftuin is pas geslaagd als deze maatregelen vervolgens ook kans maken om daadwerkelijk op grote schaal te worden geïmplementeerd en daarmee ook ruimte wordt gegenereerd voor ontwikkeling: voor melkveehouders en voor andere economische sectoren en voor natuur. Welke prikkels en/of arrangementen zijn dan in beeld? Wat zijn de randvoorwaarden voor het succesvol kunnen inzetten van maatregelen? Hoe verhouden de maatregelen zich tot wet- en regelgeving? En hoe zijn de maatregelen te borgen en te handhaven? Deze vragen stonden centraal tijdens de interviews.

Dat leverde 3 mogelijke arrangementen op:

- Ketengerichte arrangementen: veevoer en zuivel. Hoe kan de keten bijdragen aan vermindering van ammoniakemissie?

- Het voerspoor lijkt mogelijkheden te bieden, met als centrale vraag hoe te komen tot minder eiwitrijke rantsoenen voor het melkvee? Eiwitarme aanvullingen in het rantsoen zijn dan een optie. Aanvullend kunnen deze bovendien ook gentech soja vervangen. En bedrijven zoeken naar mogelijkheden om kringlopen te sluiten en hun $\mathrm{CO} 2$ uitstoot te verlagen.

- Daarnaast is het de vraag hoe reductie van ammoniakemissie een plek kan krijgen in de doelen van de zuivelketen. Op welke wijze kan de zuivelsector differentiëren in de melkprijs? En op welke termijn? Is de consument bereid hiervoor te betalen?

- Integraal gebiedsgerichte arrangementen. In het veenweidegebied blijken sommige maatregelen om ammoniakemissie te reduceren ook bij te dragen aan verbetering van waterkwaliteit, tegengaan van bodemdaling en terugdringen van $\mathrm{CO} 2$ uitstoot. De optelsom leidt dan tot extra maatschappelijke winst. Dat leidt tot de volgende vragen: hoe zou je in een integrale gebiedsgerichte benadering het nemen van deze maatregelen kunnen uitwerken als een groenblauwe dienst met een financiële beloning? Hoe hoog zou die beloning moeten zijn om voldoende aantrekkelijk te zijn? En kan het nemen van die maatregelen ook afdoende worden geborgd?

- Depositiegerichte arrangementen. Zou de melkveehouderij een deel van de stikstofopgave van derde partijen (bijvoorbeeld de Rotterdamse Haven) voor zijn rekening kunnen nemen? Wat is de bereidheid van partijen om daar voor te betalen en is dat voldoende voor melkveehouders om in beweging te komen? Hoe doorbreken we daarbij de huidige strikte scheiding tussen landbouw en industrie in het $\mathrm{N}$-depositiebeleid? Hoe vertaal je emissie in depositie? Hoe kun je lange termijn contracten sluiten? Welke rol kan een Stikstofbank daarbij spelen? Hoe en hoeveel zou je moeten afromen om te zorgen dat de natuur er ook van profiteert?

\subsection{Verdieping van de drie arrangementen}

\subsubsection{Ketengerichte arrangementen}

Eiwitarme aanvullingen in het rantsoen op extensieve melkveebedrijven in het veenweidegebied verlagen de ammoniakemissie. Deze inzet wint aan meerwaarde als ie vanuit de keten wordt ondersteund. 


\section{Mogelijke casussen}

- Bedrijven zoeken naar mogelijkheden om kringlopen te sluiten en hun CO2 uitstoot te verlagen. Zo zou Heineken graag een groter deel van het nevenproduct bierbostel uit de brouwerij in Zoeterwoude in de directe omgeving willen afzetten. De vraag is dan of het mogelijk is om bierbostel te splitsen in een eiwitrijke en een eiwitarme stroom en die laatste stroom af te zetten in het westelijke veenweidegebied? En hoeveel draagt dat dan bij aan minder ammoniakemissie, minder CO2-uitstoot door transport en/of beperking van de verbouw van snijmais in het veenweidegebied?

- De Nederlandse zuivelketen wil, mede vanuit een steeds luider klinkende maatschappelijke wens, zoveel mogelijk verantwoord geproduceerde grondstoffen inzetten. Eiwitarme aanvullingen in het rantsoen kunnen dan mogelijk gentech soja vervangen.

\section{Mogelijke betrokkenen:}

- pilotboeren: twee intensieve en twee extensieve boeren

- partners: Heineken en Bel Leerdammer/RFC/andere zuivelketen

- andere partijen: bedrijven die kunnen extraheren/centrifugeren, partijen die een inschatting van de markt voor de eiwitrijke stroom kunnen maken.

- provincies: ZH

Te onderzoeken ketengerichte maatregelen

In onderstaand schema zijn de mogelijke maatregelen in beeld gebracht:

\begin{tabular}{|c|c|c|c|c|}
\hline \multicolumn{2}{|c|}{ Maatregel } & $\begin{array}{l}\text { Melkveehouders } \\
\text { Minder } \\
\text { ammoniakemissie } \\
\text { door minder RE in } \\
\text { rantsoen }\end{array}$ & $\begin{array}{l}\text { Heineken } \\
\text { Minder CO2-uitstoot door } \\
\text { minder transport- } \\
\text { bewegingen door afzet in de } \\
\text { regio }\end{array}$ & $\begin{array}{l}\text { Zuivelindustrie } \\
\text { Inzet op } \\
\text { weidegang }\end{array}$ \\
\hline 3) & $\begin{array}{l}\text { Extra eiwitrijke bierbostel in } \\
\text { rantsoen inten \sieve bedrijven ipv } \\
\text { soja }\end{array}$ & & Idem & $\begin{array}{l}\text { Minder gen-tech } \\
\text { soja in rantsoen }\end{array}$ \\
\hline 4) & $\begin{array}{l}\text { Inzet andere eiwitarme producten } \\
\text { in rantsoen extensieve bedrijven }\end{array}$ & $\begin{array}{l}\text { Minder ammoniak- } \\
\text { emissie door minder } \\
\text { RE in rantsoen }\end{array}$ & & \\
\hline 5) & $\begin{array}{l}\text { Onderzoek naar splitsen van } \\
\text { bierbostel in een eiwitrijke en } \\
\text { eiwitarme stroom (technisch en } \\
\text { economisch) }\end{array}$ & & $\begin{array}{l}\text { Verdere verwaarding van } \\
\text { een nevenproduct }\end{array}$ & \\
\hline
\end{tabular}

\section{Mogelijke aanpak}

- Via "sigarendoos"- berekeningen: welke meerwaarde zou er kunnen zijn voor ammoniak en CO2uitstoot m.b.t. transport, areaal snijmais in veenweidegebied en gen-tech vrije soja?

- Doorrekenen effecten op bedrijfsniveau met kringloopwijzers

- Verkenning van mogelijkheden om bierbostel te splitsen in een eiwitrijke en een eiwitarme stroom i.s.m. Heineken en verwerkende partijen

- Verkennen van mogelijke inzet van andere eiwitarme producten

- Verkenning van de inzet van eiwitrijke stroom als vervanging van mais of soja i.s.m. zuivelindustrie

- Waarderingsgesprekken met Heineken, RFC, Bel Leerdammer, Nemelco

- In kaart brengen bedrijfseconomische meerwaarde

- In kaart brengen mogelijkheden voor borging. 


\subsubsection{Integrale gebiedsgerichte arrangementen}

Veel maatregelen om ammoniakemissie te reduceren dragen in het veenweidegebied ook bij aan verbetering van waterkwaliteit, tegengaan van bodemdaling en terugdringen van $\mathrm{CO} 2$ uitstoot. De vraag is of die optelsom in een concreet gebied ook om te zetten is in een optelsom van "beloningen" voor de boer. Maakt dat het nemen van deze maatregelen daarmee voldoende aantrekkelijk? En kan dat ook afdoende worden geborgd?

\section{Gebiedskeuze pilot}

In onderstaand schema zijn relevante Natura 2000 gebieden in het Westelijk Veenweidengebied beoordeeld op geschiktheid voor een pilot aan de hand van enkele criteria. Hieruit rolt een voorkeur voor het gebied rondom de Nieuwkoopse Plassen en De Haeck. Botshol zou een alternatief kunnen zijn.

\begin{tabular}{|c|c|c|c|c|c|}
\hline \multirow[t]{2}{*}{ aiteria } & \multicolumn{5}{|c|}{ Natura 2000gebieden- habitatriditlijn } \\
\hline & $\begin{array}{l}\text { Nieuwkoopse Plassenen De } \\
\text { Haedk }\end{array}$ & $\begin{array}{l}\text { Zouwe Boezerm/ } \\
\text { UiterwaardenLek }\end{array}$ & Botshol & $\begin{array}{l}\text { Naardermeer/ Oostelijke } \\
\text { Vechtplassen }\end{array}$ & $\begin{array}{l}\text { Wormer- en Jisperveld \& } \\
\text { Kal verpol der } \\
\text { / Il perveld, Varkensl and, } \\
\text { Oostzanerveld \& Twiske / } \\
\text { Elandspolder/ Pol der } \\
\text { Westzaan/ Polder Zeevang/ } \\
\text { Markermeer ljmeer }\end{array}$ \\
\hline agrariers (deelnemers) & $\begin{array}{l}\text { Amo Plomp (Wilnis), Jaco } \\
\text { Kastelein (Bodegraven), } \\
\text { Bartlo Hoogendijk } \\
\text { (Driebruggen), Jan } \\
\text { Graveland (Oudewater), } \\
\text { (Wouter Beukeboom } \\
\text { Hazerswoude-dorp) }\end{array}$ & \begin{tabular}{|l} 
Jan Christiaan Anker \\
(Stolwijk), Jaap Schep \\
(Bergambadht), Mattias \\
Verhoef (Brandwijk)
\end{tabular} & $\begin{array}{l}\text { Richard Korrel (Ouderkerk } \\
\text { ad Amstel), Amo Plomp } \\
\text { (Wilnis) }\end{array}$ & & Jaap Pronk \\
\hline collectief & $\begin{array}{l}\text { Rijn \& Gouwe Wericke, } \\
\text { Holl andse Venen, Rijn, } \\
\text { Vedht en Venen }\end{array}$ & $\begin{array}{l}\text { Collectief Al blasserwaard/ } \\
\text { Vijfheerenlanden }\end{array}$ & Rijn, Vecht en Venen & $\begin{array}{l}\text { Collectief Noord-Hblland } \\
\text { Zuid, Rijn, Vedht en Venen }\end{array}$ & Water, Land en Dijken \\
\hline waterschap & HHR, HDSR, AGV & WSRL, HDSR & AGV & AGV & HHNK \\
\hline keten & $\begin{array}{l}\text { RFC, Bel Leerdarmer, } \\
\text { (Nemelco) }\end{array}$ & RFC, Nemelco & RFC & & RFC \\
\hline \multicolumn{6}{|l|}{ gemeente } \\
\hline provinae & $\mathrm{ZH}, \mathrm{UT}$ & $\mathrm{ZH}, \mathrm{UT}$ & UT, NH & $\mathrm{NH}, \mathrm{UT}$ & $\mathrm{NH}$ \\
\hline
\end{tabular}

Mogelijke betrokkenen

- pilotboeren: Plomp (Wilnis), Kastelein (Bodegraven), Hoogendijk (Driebruggen), Graveland (Oudewater), (Beukeboom, Hazerswoude-dorp)

- collectieven: Rijn \& Gouwe Wiericke, De Hollandse Venen, Rijn, Vecht en Venen

- waterschappen: HHR, HDSR, AGV

- melkfabriek: RFC, Bel Leerdammer, Nemelco

- provincies: ZH, UT

Mogelijke integrale maatregelen

In onderstaand schema zijn mogelijke integrale maatregelen in beeld gebracht:

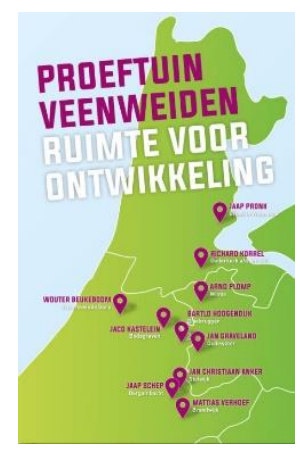

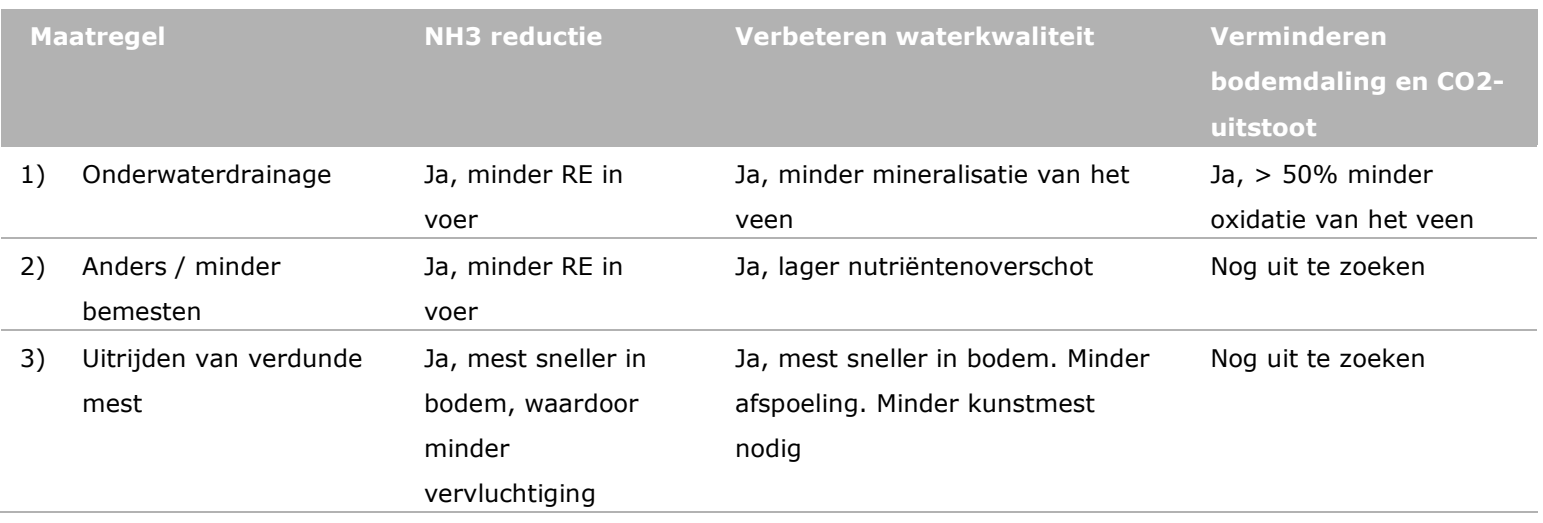




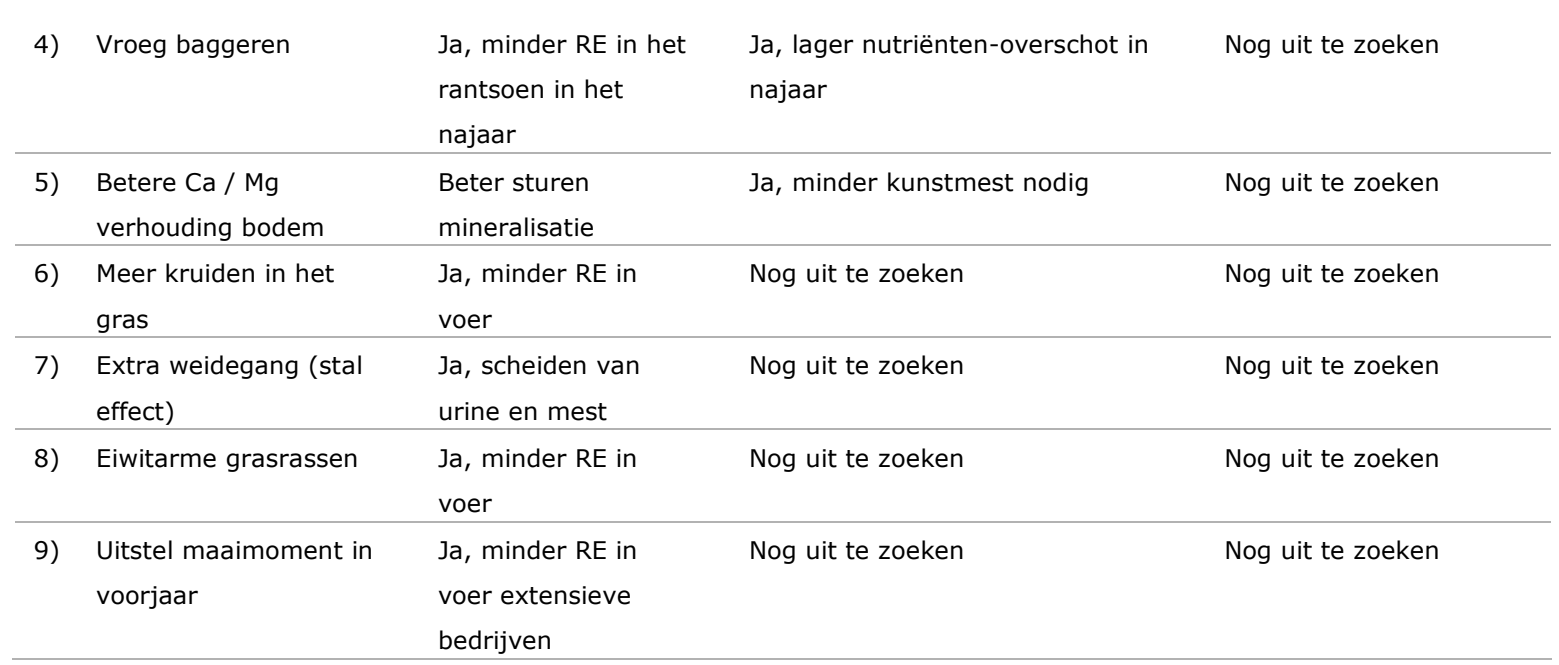

\section{Mogelijke aanpak (Nieuwkoopse Plassen)}

- Begin met "sigarendoos"-berekeningen: welke meerwaarde er zou kunnen zijn voor ammoniak, waterkwaliteit, bodemdaling en bedrijfsresultaat? Zodat er een belofte ligt.

- Referentiesituatie bepalen (ammoniakemissie, waterkwaliteit, bodemdaling)

- Bedrijfsspecifieke plannen; welke maatregelen worden genomen? (=WP2)

- Doorrekenen mogelijke effecten van de maatregelen op verschillende onderwerpen.

- Extrapolatie naar gebiedsniveau

- Waarderingsgesprekken:

- Provincie/ Aerius: wat betekent dit in PAS? Wat levert dit de boer op?

- Provincie: Wat levert dit op voor provinciale doelen en kan de provincie bijdragen aan benodigde investeringen?

- Waterschap: welke onderdelen zijn in te passen in de blauwe diensten? Wat kan en wil het waterschap (structureel) bijdragen aan deze investeringen?

- Overzicht 'waarderingspakket' en in gesprek hierover met (betrokken) boeren. Is dit voldoende om boeren over de streep te trekken?

- In kaart brengen mogelijkheden voor borging.

\subsubsection{Depositiegerichte arrangementen}

$\mathrm{N}$-depositie op natuurgronden heeft meerdere bronnen: naast ammoniak uit de veehouderij gaat het ook om depositie van NOx uit industrie en wegverkeer. Deze depositie beperkt de ontwikkelruimte van deze sectoren. Benodigde maatregelen zijn meestal duurder dan maatregelen in de landbouw. De kernvraag is dan ook welke mogelijkheden er zijn om tot uitruil (en gelijktijdige afroming) van emissierechten te komen en zo maatregelen te nemen waar deze het meest kosteneffectief zijn.

Mogelijke betrokkenen en concrete casussen

- Gebiedsgericht koppelen aan de Nieuwkoopse Plassen

- Twee mogelijke casussen

- Havenbedrijf Rotterdam

- A2 traject Utrecht - Amsterdam

- In geval van Havenbedrijf Rotterdam is er de mogelijkheid om aan te sluiten bij de samenwerkingsovereenkomst Vermindering Stikstofdeposities Rijnmond en Omgeving

- Betrokken partijen: Natuur- en milieufederatie Zuid Holland, Havenbedrijf Rotterdam, Deltalinqs, Rijkswaterstaat, provincies Zuid-Holland en Utrecht

Mogelijke aanpak

- Via "sigarendoos"-berekening inschatten hoeveel NH3 reductie mogelijk en nodig is om tot substantiële NOx winst te komen. Met gebruikmaking van Aerius

- Kosten in beeld brengen. Hoe verhouden de kosten van maatregelen in de melkveehouderij zich tot de kosten in de haven en voor wegverkeer? 
- Bandbreedte in kaart brengen van effecten ammoniakmaatregelen op melkveebedrijven i.r.t. afstand tot natuurgebieden. Effectiviteit en kosteneffectiviteit

- In kaart brengen randvoorwaarden voor uitruil (omrekeningsfactoren, locaties, etc)

- In beeld brengen benodigde/mogelijke afromingspercentages

- Ontwikkelen uitruilmodel

\subsection{Feedback van stakeholders op de drie arrangementen}

Tijdens de workshop 'Opties voor ammoniak-arrangementen' in december 2016 is samen met stakeholders ingegaan op de volgende vragen:

1. Welke arrangementen zijn perspectiefvol (is onze analyse juist of zien we dingen over het hoofd)?

2. Hoe zetten we de 3 arrangementen om in pilots? Welke aanpak, doelstellingen, resultaatformulering?

3. Hoe willen de stakeholders betrokken zijn en wie neemt welke rol op zich bij uitvoering van de pilots?

Daarbij gaven de deelnemers aan dat het, als referentie, zinvol is om het effect van de arrangementen af te zetten tegen het effect van 'harde' ingrepen, direct grenzend aan het natuurgebied (bijv. 6 bedrijven helemaal uitkopen, of 10 bedrijven van 200 naar 100 koeien en biologisch, 20 bedrijven uitrusten met de laatste generatie luchtwassers)? Wellicht duur, maar wel plain \& simple.

\subsubsection{Feedback op het ketengerichte arrangement}

Helaas viel de workshop samen met het hoogtepunt van de discussie over de fosfaatwetgeving. Hierdoor konden de uitgenodigde duurzaamheidsmanagers van twee zuivelbedrijven (Friesland Campina en BEL Leerdammer) niet aanwezig zijn op de workshop.

In 2017 is alsnog succesvol met hen verder gepraat over dit arrangement. Friesland-Campina, Rabobank en het Wereld Natuur Fonds waren op dat moment bezig met de ontwikkeling van de biodiversiteitsmonitor, met bijbehorende kritische prestatie-indicatoren (KPI's). Daarbij werd onder meer de vraag opgeworpen of een KPI in relatie tot ammoniakemissie per ha of per GVE zou moeten worden uitgedrukt. Uiteindelijk is gekozen voor ' $k g$ ammoniakemissie per ha'. De biodiversiteitsmonitor is later geadopteerd door de Duurzame Zuivelketen (NZO en LTO Nederland).

Overigens was er tijdens de workshop bij de aanwezige melkveehouders de nodige scepsis of het werken met KPI's wel zou gaan werken in de praktijk.

\subsubsection{Feedback op het integraal gebiedsgerichte arrangement}

Vraag 1: Voor welke maatregelen 'voelen' we op voorhand het meeste? En waarom?

- Hier worden veenweide-gerichte maatregelen genoemd, maar om een goede gebiedsgerichte casus door te rekenen is het ook interessant rekening te houden met de mogelijkheden van het voerspoor, de samenstelling van de veestapel en bedrijfsstijlen (bijv. weidegang, extensief).

- Bedrijfsstijlen met veel weidegang. Kanttekening is dat er zoveel eiwit in het gras zit, dat dit voor $\mathrm{NH} 3$ emissie soms negatief uitpakt.

- Stoplichtsysteem voor mest uitrijden. Onderscheid in bodemsoort, type machine, bandenspanning, etc. Keuze te maken w.b. fijnmazigheid van het systeem. Uitrekenen wat het scheelt op gebiedsniveau.

- Luchtwasser bij melkveestallen. Geen veenweide-specifieke maatregel, maar wel interessant om door te rekenen.

- Substantiële hoeveelheid natuurgrond in areaal melkveehouder. Minder eiwit in ruwvoer. Op gebiedsniveau kun je bekijken of je een deel van het gebied natuur(lijker) kunt maken, bijv. via Groen Blauwe Diensten (GBD). 
- Jongvee weiden op natuurgronden.

- 9 maanden opslag zodat je kunt uitrijden als het gewas erom vraagt.

- Gedragsverandering is grootste uitdaging! Zie te achterhalen hoe een boer bepaalt of zijn vee naar binnen moet, of zijn mest al uitgereden kan worden, of hij wel of niet gaat maaien, etc. Hoe krijgen we het vizier van "meer vee, meer melk" naar "lagere kosten, betere prijs" voor product, andere inkomsten? Boeren worden nu erg geleid door melkcontrole: een teruggang van productie wordt gezien als negatief, ongeacht of ook de kosten naar beneden zijn gegaan.

- Gras groeit door klimaatverandering steeds langer door, maar het late najaarsgras wordt niet binnen gehaald. Koeien langer naar buiten. Of schapen in het najaar.

Vraag 2: Waar zitten, vooraf gezien, de meeste potenties voor 'opbrengsten' voor de boer? NH3 pakket in GBD systeem. Hoogheemraadschap AGV werkt aan bodempakket waar NH3 wordt meegenomen. Zoek de samenwerking. WaterLand\&Dijken is geïnteresseerd in dergelijk pakket. Inschatting; 4 tot 5 collectieven zijn wel zover dat ze kunnen/ willen nadenken over uitbreiding van pakketten.

Vraag 3: Wanneer is de uitkomst van de pilot succesvol? Kunnen we dit SMART maken?

- Maak een krachtenveldanalyse. Hoe borgen we dat goede ontwikkeling in het project wordt voortgezet in komende 12 jaar? We hebben de invloed van fosfaatrechten gezien. Wat kunnen we verwachten voor $\mathrm{NH3}$ ?

- Thema 'milieu' interessant voor collectief/agrarisch natuurbeheer. Door het beleid van kerngebieden komen 200 van de 500 leden van WLD niet meer in aanmerking voor agrarisch natuurbeheer. Voor de ledenbinding zijn nieuwe concrete projecten gewenst.

- Focus niet teveel op 1 gebied (Nieuwkoop) of deze 5 deelnemers. Verschillende maatregelen kunnen misschien beter/ ook elders worden uitgetest. Of op een ander schaalniveau. Denk aan het stoplichtsysteem. Wellicht onderzoeksvraag (rekenexercitie) op gebiedsniveau focussen op Nieuwkoop, maar implementatie-pilots uitvoeren in andere gebieden. WLD? Groot WilnisVinkeveen (net klaar met gebiedsproces en klaar voor volgende stap).

- In Nieuwkoop is in het verleden al een groot herstelproject uitgevoerd. De Haven heeft daar in geïnvesteerd. Dat kan een complicerende factor zijn.

\subsubsection{Feedback op het depositiegerichte arrangement}

Vraag 1: Voor welke maatregelen 'voelen' we op voorhand het meeste? En waarom?

- Het gaat vooral om managementmaatregelen. Dan is een dubbele borging nodig:

- De te reduceren hoeveelheid ammoniak uit de vergunning halen

- Elk jaar via KLW aantonen dat je de reductie ook haalt (uitmiddelen over meerdere jaren mogelijk)

- Maar daarmee ben je er niet. Want feitelijk leg je ook een beperking op het grondgebruik. Wat betekent dat voor verkoopwaarde en verpachterswaarde? Moet de verpachter er mee akkoord gaan?

- In het voerspoor is nog veel winst mogelijk. Maar hoe reken je die winst toe: aan verlaging van de gehalten in het voer of aan het management van de boer? Om het nog gecompliceerder te maken: het voerspoor is ook onderdeel van de PAS-afspraken.

Vraag 2: Waar zitten, vooraf gezien, de meeste potenties voor 'opbrengsten' voor de boer?

- Inzet is gericht op win-win-win: ontwikkelruimte + $€ €$ voor de landbouw, ontwikkelruimte voor industrie/haven tegen lagere kosten, minder depositie natuurgebieden (=afromen transacties). 
- Grote verschillen tussen gebieden v.w.b. bijdrage landbouw/industrie/haven/etc. Daarom ook de vraag of handel tussen gebieden mogelijk kan worden gemaakt.

- Ga je aan de slag op individueel of op gebiedsniveau? Individueel niveau is het meest precies, maar ook administratief complex en het moeilijkst uit te leggen ("waarom krijgt mijn buurman per kg ammoniak meer geld dan ik: hij ligt ten westen van het natuurgebied en jij ten noorden").

- Is dit allemaal wel nodig? Kan je niet beter aan de slag in het voerspoor?

- Wil de landbouw wel verhandelen? Wil men de ruimte niet liever voor eigen ontwikkeling gebruiken?

Vraag 3: Wanneer is de uitkomst van de pilot succesvol? Kunnen we dit SMART maken?

- Complicerende factor is dat wanneer de landbouw werkt aan reductie van $\mathrm{NH3}$ en deze vervolgens te koop aanbiedt aan het havenbedrijf, dat het havenbedrijf deze ruimte op dat moment net nodig heeft.

- Twijfel over het betrekken van de emissiebronnen 'consumenten' en 'buitenland'. Want wie zijn de te adresseren stakeholders? Dus met die gestippelde pijlen in de figuur kun je niks.

- Het gele balkje 'onbekend' = verschil tussen berekend en gemeten. Dat verschil wordt in de loop der tijd vanzelf steeds kleiner.

- Hoe ga je om met bedrijven die stoppen (of in stappen afbouwen)? Mogen die hun ammoniak-ruimte ook verhandelen? Afstemming met PAS-regels nodig!

- Hoe ga je om met veranderende regelgeving? Stel de PAS moet de komende jaren worden aangescherpt met extra maatregelen die nu nog onder 'management' vallen, wat gebeurt er dan met de boer die deze 'ammoniakruimte' al heeft verkocht?

- Hoe borg je de rechtszekerheid? De Haven is

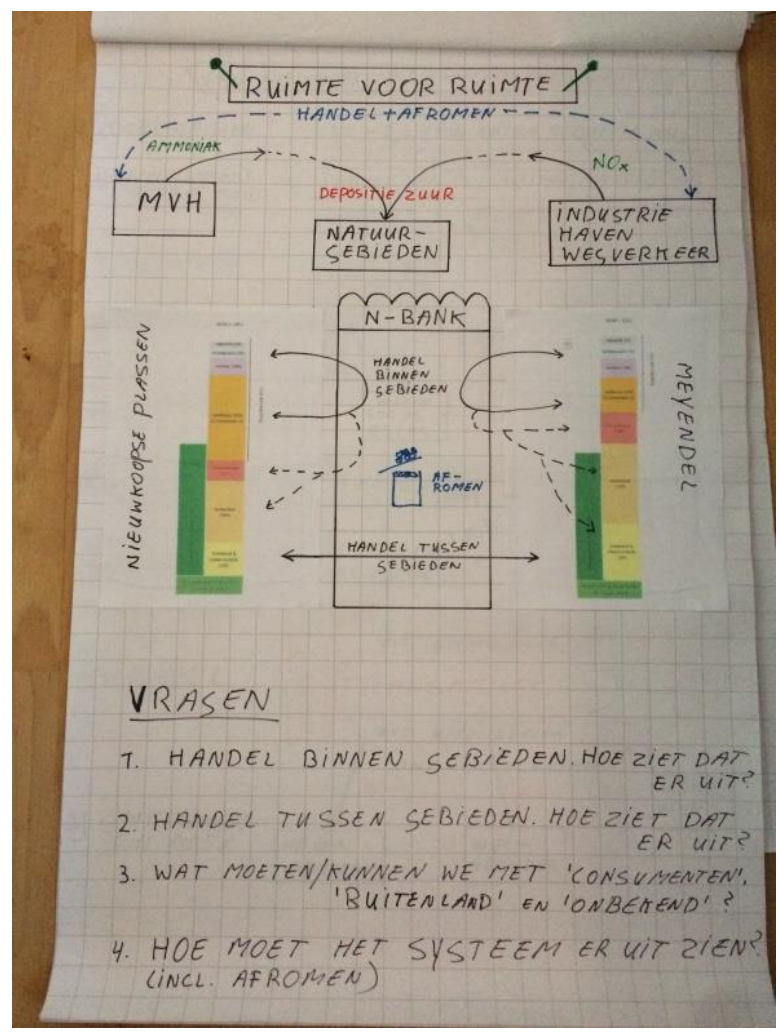
geïnteresseerd in handel, maar het moet wel voldoende hard zijn. Een systeem gericht op managementmaatregelen is kwetsbaar.

- Voor welke tijd maak je afspraken? Voor 1, 5, of 10 jaar of voor altijd (=uit de vergunning)? Aan de andere kant van de N-bank maakt het Havenbedrijf het liefst afspraken voor 20-50 jaar. Kan de $\mathrm{N}$-bank voorzien in discrepanties tussen vraag en aanbod?

\subsubsection{Beleidsgerichte 'arrangementen'}

Tenslotte gaven de deelnemers aan de workshop aan dat er ook moet worden gekeken of bepaalde maatregelen via regelgeving kunnen worden ingevoerd. Daarbij moet allereerst worden gedacht aan een maatregel als het verdunnen van mest bij aanwenden. Die maatregel is kosteneffectief en wordt toch nog maar weinig toegepast. Is het mogelijk om de implementatie van zo'n maatregel te versnellen en te verbreden door hem via regelgeving "verplicht" op te leggen? 


\section{$4 \quad$ Conclusies en aanbevelingen}

\section{Conclusies}

1. Er liggen potentieel mogelijkheden om agrariërs via arrangementen te verleiden tot het nemen van maatregelen die de ammoniakemissie verminderen.

2. Het gaat om integraal gebiedsgerichte, ketengerichte en depositiegerichte arrangementen.

3. Daarbij is nog wel sprake van de nodige belemmeringen, voetangels en klemmen van praktische, principiële en methodologische aard.

\section{Aanbevelingen}

Aanbevolen wordt om:

- Het ketengerichte arrangement verder uit te werken in samenspraak met betrokkenen in de voerketen en de zuivelketen.

- Het integrale gebiedsgerichte arrangement verder te verkennen via een of enkele praktijkexperimenten.

- Het depositiegerichte arrangement, ondanks alle vraagtekens, verder uit te werken via literatuurstudie en in samenspraak met betrokkenen.

- Ook te kijken naar de mogelijkheden van regelgeving (beleidsgerichte spoor).

\section{Rapportages}

De uitwerking van deze vier sporen is terug te vinden in de volgende Proeftuin Veenweidenrapportages.

\section{Ketengericht}

- $\quad$ Rapport: "Naar een ketengerichte aanpak om ammoniakemissie te reduceren. Ontwerp en toetsing"

\section{Gebiedsgericht}

- $\quad$ Rapport: "Naar een integraal gebiedsgerichte aanpak om ammoniakemissie te reduceren. Ontwerp en pilot"

- Rapportage "Van Proeftuin Veenweiden naar Klimaatslim Boeren op Veen"

\section{Depositiegericht}

- $\quad$ Rapportage "Mogelijkheden tot vermarkten reducties in ammoniakemissie in het westelijk veenweidegebied"

- Rapport: "Naar een depositiegerichte aanpak van ammoniakemissies rond de Nieuwkoopse Plassen" 


